\title{
Strategic Thinking on Sino-Indian Cultural Exchange Based on Cinematic Perspective
}

\author{
Li Zhao ${ }^{1,2}$ \\ ${ }^{1}$ School of History \& Culture (Tourism), Sichuan University, Chengdu, 610065, China \\ ${ }^{2}$ School of Liberal Education, Sichuan University Jincheng College, Chengdu, 611731, China
}

Keywords: soft power; film; Sino-Indian cultural exchange

\begin{abstract}
The cultural exchanges between China and India have a long history and extensive content. Currently, cultural exchanges still play an essential role in bilateral relations. The film, which is welcomed by the people of both China and India, is the artistic and expressive form of culture projection. The paper explores the functions of movies in bridging cognitive differences, enhancing mutual trust between peoples of two countries, and promoting cultural exchanges as well as harmony in international relations.
\end{abstract}

\section{Introduction}

Both China and India possess more than a billion population with multiple ethnic groups. They both have passed the history of invasions by other countries, and then gone through hardships to achieve independence after the Second World War. As two of the world's largest developing countries, while inheriting their own traditional culture, they also inevitably experience strong impact from other cultures, and face the dilemmas of tradition and modernity, and of inheritance and transformation, as well as exclusiveness and inclusiveness.

Since ancient times, China and India have established extensive and close contacts. The spread of Buddhism from India to China and trade ties connected by Silk Road have brought rich spiritual and material prosperity to both countries. Since modern times, especially in the past 70 years, the bilateral relations have gone through ups and downs, from the beginning of the "Chini - Hindi Bhai Bhai" (namely "Indians and Chinese are brothers", the famous slogan of the 1950s, used to describe the friendly bilateral relations) in 1962 to trust deficit triggered by the border conflict between the two countries, and from the indifferent or even hostile to normalized in the last twenty plus years. History left the two countries in the dispute over $3500 \mathrm{~km}$ of land border, and then the "One Belt One Road" policy recently proposed by China has led the two countries to competition in the regions of Indian Ocean and South Asia. Excessive nationalism is easy to lure the two countries to fall into a trap of "security dilemma", and conversely the cultural paradigm, by endeavoring to strengthen mutual communication and to decrease cognition asymmetry, may find the path to reconciliation or even win-win solution to potential conflicts.

\section{The History of Sino-Indian Cultural Exchanges}

China and India are neighboring countries. Ji Xianlin said that "the cultural exchange between China and India is a well-deserved example of the world", which dates back to the Pre-Qin period (before $221 \mathrm{BC}$ ) in China with a history of more than two thousand years [1]. The two cultures have long interacted with each other on a wide range of subjects, including both the material and spiritual contents. From the Jin Dynasty to Sui and Tang Dynasties (265-907 AD), the cultural interaction between the two countries has reached the heyday" [2], featuring the prosperity of Buddhism in China's Tang and Song Dynasties.

In China's Southern Song Dynasty and Yuan Dynasty, however, the thriving of Hinduism and introduction of Islam gave rise to gradual decline of Buddhism in India, thus bilateral cultural exchanges shrank dramatically mainly due to the resulted lack of religious channels. The interaction 
then recovered slightly until the Ming Dynasty, characterized by Zheng He's voyages to South Asia with large-scale fleet on diplomatic missions. In 1900s, China gradually became a semi-feudal and semi-colonial country, and meanwhile India was completely colonized by the British. Hence in China there emerged numerous books about India, such as Wei Yuan's Graphical Records of Overseas Countries (Hai Guo Tu Zhi), Gong Chai's Graphical Research on Five Continents (Wu Zhou Tu Kao) etc. These books show sympathy towards sufferings and bitterness of Indian people in modern times, and also reflect the traditional friendship between the two countries. In the first half of the 20th century, the national independence movement was surging, and there was a large number of people who made outstanding contributions to the bilateral cultural exchanges, such as Zhang Binglin, Tagore, Lu Xun, etc. The cultural interaction continues to move forward after the independence of the two countries for the reason that their cultural similarities, such as the pursuit of harmony, natural way of life and humanity, have established the value basis for cooperation, whereas the differences in culture also provide possibilities for complementation and integration.

\section{Cultural Interaction and the Construction of Soft Power}

Cultural exchange is an equal and interactive process. At present, cultural communicators and prospective recipients are not subject - object relations, but two main interdependent and interactive bodies in the same cultural communication field. The "inter-subjectivity" requires that the cultural communication process should be based on the preference of audience to achieving communication effect. What's more, cultural exchanges need positive and direct publicity with both facts and reasoning, and also demand visualization of interesting stories to put across ideas. Therefore, to strengthen the mutual understanding and trust among people of different countries, tedious preaching and excessive publicity should be avoided, and diversified channels are highly recommended to promote cultural competitiveness.

Culture interaction is of great significance in enhancing a country's soft power in the international community. The theory of soft power is proposed by American scholar Joseph Nye, who has divided the national power into hard power and soft power. The former is to realize the aim by intimidating or even coercing the other nations, while the latter is by persuasion and assimilation. Soft power consists of cultural appeal, political values and international policies as three major sources. He holds the view that if a country's soft power is strong, it will get a higher international recognition, and then is likely to achieve its desires by attracting rather than coercing other countries, with smaller obstacles encountered during the process [3]. Accordingly, in the era of globalization, cultural soft power enjoys the potential to guide public opinion, which has become an indispensable competition focus on the international stage. Nonetheless, compared with hard power, the resource of soft power is more dispersed, and its effectiveness is up to the acceptance of recipients, with more obscure functions and much slower influence, requiring more flexible means during implementation. Nye also believes that Asia's ancient culture, such as art, fashion and cooking, has profoundly affected other parts of the world for centuries [4]. In the new historic period, being increasingly open and liberal to foreign cultures, China and India urgently desire to rejuvenate their abundant local culture, and strive to transform their high-quality cultural resources into the soft power of the state. In the report of the Seventeenth National Congress of the Communist Party of China(CPC) in 2007, "enhancing the soft power of national culture" has been adopted as the basic principle of national development [5]. India has also developed and demonstrated its soft power through Bollywood culture, Ayurveda and yoga. To achieve the joint goal of strengthening soft power, firstly, the two countries both need an open, equal and inclusive international cultural order; secondly, they have to coordinate and cooperate with each other during the process; thirdly, while tactically accepting the excellent elements in heterogeneous culture, they should actively search for the breakthrough point to make their cultures understood by people in the other places of the world. 


\section{The Film and Bilateral Cultural Exchanges}

The film, as a kind of mass culture, enjoys a strong appeal, high transmission efficiency as well as massive publicity force. According to Vinzenz Hediger, an expert in cinematic studies, "cinema-goers must be able to relate what is happening on the screen to what is going on in their lives" [6]. With visual and sound effects, the story is more likely to transcend language and cultural barriers, making audiences resonate, and even influencing their cultural mentality and cultural choices. The number of film production and film audience in India is already listed at the top of the world, whereas China's film industry is also booming. Cultural publicity in the form of films may play a more important role in cultural exchanges.

Indian movies is regarded as the effective medium for cultural publicity. Most Chinese know about India through Indian films. In 1955, Chinese Ministry of Culture organized "Week of Indian Films" in more than 20 cities nationwide, indicating the introduction of Indian movies for the first time. During this activity, three feature films were brought to the Chinese, with The Tramp as the most popular and influential one. In the early 1979, the film was released again in China, both the film and its theme song caused a sensation in China. In the 1980s, the Caravan was imported in China, also gaining huge success [7]. Both of the two films have shown sympathy for the poor, praising diligence, integrity and courage of ordinary people, which move millions of Chinese audience. In the 21 century, more Indian movies are released in China, winning favorable reception from even more audience. Chinese films are also having great impact in India, Jackie Chan's martial art movies and Stephen Chow's comedies help Indians understand China.

Despite the long history of cultural exchanges between China and India, the portrayal of China and the Chinese characters can be hardly found in Indian films [8], and equally there are so few Indian characters in Chinese movies.

Image of Chinese firstly appeared in the biography movie The Immortal Story of Dr. Kotnis (directed by Shantaram, released in 1946 in India). The film is about the great deeds of India doctor Kotnis, who volunteered to China to support China's anti-Japanese war. The film reflects India's friendly attitude towards China in the 1930s and 1940s, and its enthusiasm for revolutionary movements. The image of Chinese in this film is positive. On the contrary, in the Bollywood war film Haqeeqat/ Reality (directed by Anand, released in 1964), Chinese officers and soldiers in the film were deliberately depicted into the images of the "enemies" and "traitors". This film was to reflect the Sino-Indian border war of 1962, with strong political propaganda purpose and biased ideology. Chandni Chowk to China (CC2C) (directed by Advani, released in 2009) is an Indian style Kung Fu comedy, which tells the story under the background of globalization, and China and India becoming important trade partners. The movie is about the adventure of an ordinary Indian chef to China to realize his personal value and to pursue his happiness. The plot, structure, and narrative style of the film are similar to those of Kung Fu Hustle directed by Chinese director Stephen Chow, about the growth of a timid man to a Kung Fu master by overcoming obstacles in life [9]. As the first Indian film shot in China, it not only shows the Indian audience the magnificent scenery of Forbidden City, the Great Wall and the Oriental Pearl TV Tower, but also convey the core values of the Chinese people- the pursuit of harmonious life. The movie is an integration of both Indian style singing and dancing, and Chinese iconic feature- Kung Fu.

Indian images are in the Chinese films of both historical and contemporary themes. The film Xuan Zhang, was the most talked-about co-productions between China and India in 2016. The venerable monk Xuan Zhang's journey to India in $7^{\text {th }}$ century is a classic case of bilateral cultural communication and cultural diplomacy. The biographical drama's main line is the Buddhist monk's harsh pilgrimage to India to seek scriptures, while the audience could also appreciate the view of Silk Road as well as the historical sites of India. Furthermore, the Indian religious culture and civil culture are also revealed in this movie.

At the end of last century, the two countries both adopted market economy system and reform and opening up policy, ushering in the rapid economic growth and enhancement of comprehensive national strength. They both are faced with the drawbacks of modernity and need to seek salvation 
from the traditional cultural spirit. The films in contemporary themes, such as Buddies in India (2017) and Kung-Fu Yoga (2017), include historical memory and modern innovation. The former is a combination of Chinese Kung Fu elements and religious spirit, and the latter is a blend of Kung $\mathrm{Fu}$ and Indian yoga. The former is a modern version of the Journey to the West, describing how the hero to go to India to obtain spiritual salvation. The narration of Kung-Fu Yoga echoes the profound friendship between China and India in China's Tang Dynasty. The two films are also related to India's elite and ordinary people, folk customs as well as historical culture.

\section{The Film as the New Channels for Cultural Cooperation}

Bilateral cultural cooperation in the field of film, firstly, is beneficial to the culture inheritance. Secondly, it also helps to overcome the narrow nationalism to promote the cultural innovation. Thirdly, it is conducive to the interpretation of local cultural elements in the foreign culture, so as to enhance the soft power of a nation.

In the 1980s and 1990s, India began to absorb nutrients from Chinese Hong Kong films. At present, Bollywood has established into an industry cluster with numerous production bases, wide market and multiple products. What's more, it has also integrated the fashion, food, travel, and many other cultural industries into films [10]. Bollywood movies, as an important carrier of India's soft power, facilitate India not only to resist the cultural universalism caused by globalization, but also to gradually form a set of export-oriented culture dissemination system with the Indian characteristics [11]. Although big in size and large in audience, India's film industry is inseparable from China's huge market.

Nowadays, Chinese film industry, resourceful in funding and technology, is expected to learn from Bollywood experience on shaping film with national features and reinforcing cultural innovation and adaptation.

There are so many governmental or non-governmental cultural exchange activities, such as Brics Film Festival and film exhibitions, serving as good platforms for the two neighbors in Asia to co-produce more high quality movies of grand narrative subjects or modern themes to enhance the influence and competitiveness of Asian films globally.

\section{Conclusion}

With millennium-old cultural interaction history, cultural coordination and cooperation between China and India in the new era is beneficial to the enhancement of cultural adaptability, the construction of soft power, and the diversified development of world culture. Currently, as the film has become a showcase of local customs and national images and an influential means to spread values as well as ideas, how to make a systematic cultural strategy in the input and output of cultural products, how to optimize the function of official organizations to develop more favorable policies to facilitate the exchange of good movies, and how to encourage non-governmental institutions and private sectors to even more closely engage in popular intercultural communication, are deserving long-term and in-depth study.

\section{References}

[1] Ji Xianlin. Ji Xianlin’s Theory on Sino-Indian Cultural Exchange [M]. 2006: 5-6.

[2] Ji Xianlin. The History of Sino-Indian Cultural Exchange [M]. Beijing: Xinhua Publishing House.1993: 37.

[3] Nye, J. S. Soft Power. Foreign Policy[J]. 1990. 80(Fall): 153-171.

[4] Nye, J. S. Soft Power: The Means to Success in World Politics[M]. New York: Public Affairs. 2004: 83, 99.

[5] Hu Jintao. 2007. Report to the Seventeenth National Congress of the Communist Party of 
China(CPC)[DB/OL]. https://wenku.baidu.com/view/9ecc9728e2bd960590c67723.html/ Retrieved May 11, 2018.

[6] Hediger, V. 2006. The Hindu-Muslim Conflict in Bollywood Films: The Religious Conflict as a Blockbuster[DB/OL].http://en.qantara.de/content/the-hindu-muslim-conflict-in-bollywood-films-th e-religious-conflict-as-a-blockbuster/ Retrieved May 12, 2018.

[7] Liu Chaohui. 2018. Indian films are getting increasingly popular in China[DB/OL]. http://www.xinminweekly.com.cn/jctw/2018/05/09/10166.html/ Retrieved May 9, 2018.

[8] Uberoi, P. China in Bollywood. Contributions to Indian Sociology[J], 2011. 45(3): 315-342.

[9] Kishore, V. A. Sarwal and P. Patra, eds. Salaam Bollywood: Representations and Interpretations[M]. Routledge: London and New York.2016:246.

[10] Rajadhyaksha, A. The "Bollywoodization" of the Indian Cinema: Cultural Nationalism in a Global Arena[J]. Inter-Asia Cultural Studies, 2003. 4(1): 25-39.

[11] Matusitz, J. and P. Payano. Globalization of Popular Culture: From Hollywood to Bollywood. South Asia Research, 2012. 32(2): 123-138. 